\title{
Assessment of sheep fattening and marketing systems in Duna Woreda, Hadiya zone, Southern Ethiopia
}

\begin{abstract}
The study was conducted in Duna Woreda, Hadiya Zone, with the objective of assessing sheep fattening and marketing systems practiced in the area. Four Kebeles were selected based on agro-ecology and population densities of sheep. From each Kebele, 20 households were selected randomly. A total of 80 households were interviewed by using semi-structured pre-tested questionnaire. Farmers in the surveyed area practiced feeding of fattening sheep in feedlot system (60\%) and grazing and stall feeding (40\%). The high proportion of producers provided crop residues and grazing of natural grasses. The result showed $52.5 \%, 12.5 \%$ and $35 \%$ were using river water, well water and both well and river water respectively. Farmers and rural assemblers from different local markets supply animals of varying sex, age and weight to Ansho and Cafemera secondary markets. The second and most important route was through medium and large traders who collect animals from Duna woreda/Ansho areas and supply through large traders to terminal domestic markets in Hosanna and Addis Ababa. Natural pasture and house leftover were the major feed resources during the rainy season whereas natural pasture, crop residue, improved forage and house leftover were the feed resources in the dry season. Male sheep were given higher choice than females during selection. Matured sheep which are within the age range of 1-2 years had got higher choice in selection over the young ones $(68.75 \%)$. The price of fattening sheep depends on body condition, castration, age, color and ranging from 2000-4500 ETB. Exposed challenges were lack of awareness, lack of marketing channels and distance from marketing place. Both market supply and demand of sheep were typically seasonal and reaches peak during the holidays. Agricultural development agents should give attention in creating awareness for farmers by providing adequate skill and monitoring.
\end{abstract}

Keywords: farmers, fattening, marketing, sheep
Volume 9 Issue 4 - 2020

\author{
Abaynesh Assefa,' Asrat Ayza' \\ 'Duna Woreda, Livestock and Fishery Resource office expert, \\ Ethiopia \\ ${ }^{2}$ Department of Animal and Range Sciences, College of \\ Agriculture, Wolaita Sodo University, Ethiopia
}

Correspondence: Asrat Ayza, Department of Animal and Range Sciences, College of Agriculture, Wolaita Sodo University, Ethiopia, Email ayzaasat@gmail.com

Received: June 22, 2020 | Published: August 28, 2020
Abbreviations: ESGPIP, Ethiopia sheep and goat productivity improvement program; DWARDO, Duna Woreda agriculture and rural development office

\section{Introduction}

Ethiopia has the largest livestock population in Africa with estimated number of 57.83, 28.89, 10.37, 1.23, 56.87 and 10 millions of cattle, sheep, goats, equine, camel, poultry and bee colonies respectively. Sheep have a great environmental adaptability, short production cycle, faster growth rates, easy management, low investment capital and low feed requirement as compared to large ruminants. ${ }^{1}$ Sheep are the major economically important in Ethiopia playing an important role in livelihood of resources poor farmers. They provide their owners with a vast range of products and services such as meat, skin, hair, wool and manure and as means of saving and investment. Similarly, the countries have huge and diverse sheep population and genetic diversity is the requisite for the present and future livelihoods of a large number of poor farmers. ${ }^{2}$

Sheep serve as living bank for their owner and immediate cash need and ensures against crop failure especially where land productivity is low and a reliable due to erratic rainfall, sever erosion, too frost and logging problems. In the country, the highland sheep are important source in the diet of poor farmers, help in providing extra income and support for survival of many farmers, the income obtained from sheep are used to purchase household commodities and farm inputs. ${ }^{3}$ Lack of grazing area due to human population growth and crop land expansion has forced the small scale farmers of Ethiopia to recognize the significance of sheep. ${ }^{4}$

Fattening/Finishing involves intensive feeding of sheep to slaughter weight with adequate finish (fat deposit) in feedlots. This targets the local market that has high demand for fat animals. The operation of large feedlots by export slaughter houses and independent feedlot operators (on-farm feedlots) is becoming feasible. The principal functions of such feedlot operations are to assemble large numbers of sheep, often coming from different genetic and management backgrounds, and produce a product of acceptable standard..$^{5}$ A current carcass yield of Ethiopian sheep average was42 percent. Improving carcass yield results in more meat available for domestic consumption/export and directly increases producer incomes. Short term intensive feeding using locally available feedstuffs is a strategy that can be employed to increase animal live weights and subsequent carcass yields. Short term intensive feeding prior to sale is economically more feasible than the current systems where animals are kept for long periods of time on maintenance level feeding. Cost benefit analyses of shortterm fattening compared to maintenance feeding for extended periods show that short term fattening can be a viable business venture.

The domestic market remains to be the largest consumer of Sheep in Ethiopia even though exports have been increasing over the past 
years. A fattening operation can be of various sizes. One can fatten a single sheep up to many hundreds or even thousands depending upon availability of capital, market access, etc. operations ranging from backyard to large scale fattening should be promoted. This can be done through provision of training, credit, fostering market access, etc. $^{5}$

Such practice is the most common traditional fattening practice among farmers in various parts of Ethiopia. The small scale sheep fattening in Ethiopia follows a seasonal operation with a peak during Easter, Christmas, Ethiopian New Year and Muslim festivities. Marketing of sheep are completed through negotiation. In the process of sheep marketing, farmer, middle men and traders are involved. The price of fattening sheep depends on body condition, castration, age, color and ranging. Ethiopia has suitable agro-ecology which is best for sheep production. Sheep production has been practiced in the country for the exploration of meat, skin and manure. ${ }^{6}$ As different areas of the country, sheep production is common in Duna Woreda, which is one of the eleven Wored as found in Hadiya zone, South Ethiopia with suitable agro ecology that makes the Woreda potential for sheep production and marketing. Even though the district is potential in sheep production, there is no complied data and reliable information on sheep fattening and marketing system practiced. Therefore, this study was aimed to assess fattening and marketing systems of sheep practiced in the area.

\section{Materials and methods}

\section{Description of the study area}

Duna Woreda is one of the eleven Woredas in Hadiya Zone, South Ethiopia. The Woredashares boundaries with Kambata Tambaro zone in the North and East, and Soro Woreda in the South and West. The Woreda is astronomically located between $7015^{\prime} \mathrm{N}$ and $7025^{\prime} \mathrm{N}$ Latitudes and between 370 32' E and 370 46' E Longitudes. In terms of administration, Duna Woreda is sub-divided in to 31 rural and 1 urban Kebeles. Its main town, Ansho, is located at about 269kms Southwest of Addis Ababa, and $178 \mathrm{kms}$ Northwest from Hawassa (the capital of the region) and $42 \mathrm{kms}$ from zonal major townHosannato the South direction. ${ }^{7}$ The topography ranges from 1,500 to 2,926 meters above sea level. The climate characterized as follows; maximum monthly temperature occurs in April $\left(19.8^{\circ} \mathrm{c}\right)$ whereas minimum monthly temperature occurs in December $\left(16.5^{\circ} \mathrm{c}\right)$ over the ten year. The mean annual temperature is $18^{\circ} \mathrm{c}$. The rainfall is characterized by uneven distribution throughout the year. The highest rainfall occurs from the end of spring to the beginning of autumn season (May-September). ${ }^{7}$

\section{Sampling technique}

Agro-ecologically, the Woreda is classified into 'Dega'(25 Kebeles), 'Woina Dega' 5 Kebeles and 2 Kebeles in 'Kola'. ${ }^{7}$ From 'Dega' 3Kebelesand 1 Kebele from 'Woina dega' were selected purposively based on population density of sheep and market potential. From each Kebele, 20 households that are familiar with the practice of sheep fattening were selected using systematic random sampling technique. A total of 80 households were interviewed by using pretested semi-structured questionnaire regarding sheep fattening and marketing practices.

\section{Data collection}

Both primary and secondary data were used for this study. The primary data was obtained by preparing semi-structured questionnaire and personal observation whereas the secondary data was collected from written documents and agricultural office of Duna Woreda.

\section{Data analysis}

The collected data were arranged, summarized and analyzed by using simple descriptive statistics like percentage, mean and frequencies and presented by using tables.

\section{Result and discussion}

\section{Socio-economic characteristic of the respondents}

From the socio-economic characteristics of the households, it is reported that ( 85 percent) of household members were males while (15 percent) were females. The educational background of the respondents indicated that ( 56.25 percent) of the household members are illiterates (32.5 percent) attended primary school (10 percent) attended secondary and the (1.25 percent) rest hold diploma. The majority of the sample households have large family size. Of the total, half (51.25 percent) of respondents had a family size of 4-7 while a few (33.75 percent) of respondents had family size 1-3 the rest greater than 8 family size (15 percent).In terms of occupation, the almost all of the households ( 98.75 percent) of the respondent are in predominantly engaged in subsistence farming and produce cereal crops such maize, and sorghum, etc. for their house consumption. Income sources a number of activities such as farming, livestock keeping, small scale business and government worker (Table 1).

Table I Socio-economic characteristic of the respondents

\begin{tabular}{|c|c|c|c|}
\hline Parameters & & $\begin{array}{l}\text { Frequency } \\
(\mathbf{N}=\mathbf{8 0})\end{array}$ & $\begin{array}{l}\text { Percentage } \\
(\%)\end{array}$ \\
\hline \multirow[t]{2}{*}{ Sex } & Male & 68 & 85 \\
\hline & Female & 12 & 15 \\
\hline \multirow[t]{3}{*}{ Age } & $15-25$ & 10 & 12.5 \\
\hline & $26-45$ & 39 & 48.75 \\
\hline & $>45$ & 31 & 38.75 \\
\hline \multirow[t]{4}{*}{ Education status } & Illiterate & 45 & 56.25 \\
\hline & Primary & 26 & 32.5 \\
\hline & Secondary school & 8 & 10 \\
\hline & Diploma and above & I & 1.25 \\
\hline \multirow[t]{3}{*}{ Family size } & 3-Jan & 27 & 33.75 \\
\hline & 7-Apr & 41 & 51.25 \\
\hline & $>8$ & 12 & 15 \\
\hline \multirow[t]{2}{*}{ Occupation } & Farmer & 79 & 98.75 \\
\hline & $\begin{array}{l}\text { Government } \\
\text { worker }\end{array}$ & I & 1.25 \\
\hline \multirow[t]{4}{*}{ Income source } & Crop farming & 51 & 63.75 \\
\hline & Livestock keeping & 10 & 12.5 \\
\hline & Small business & 18 & 22.5 \\
\hline & $\begin{array}{l}\text { Government } \\
\text { worker }\end{array}$ & I & 1.25 \\
\hline Total & & 80 & 100 \\
\hline
\end{tabular}




\section{Fattening system of sheep identified in the study area}

Farmers in the surveyed area practice feeding of fattening sheep in feedlot system ( 60 percent) and grazing and stall feeding (40 percent). The high proportion of producers provides crop residues and grazing of natural grasses. The two option of stall feeding, and stall feeding with grazing were previously reported from southern Ethiopia. The result showed housing system of sheep fattening (33.75 percent) common with total sheep and (66.25 percent) separate for fattening sheep in the study area.

Purposes of keeping sheep as respondents: The main purposes of keeping sheep in the studied area were for cash income (56percent), for security (30percent) and for home consumption by slaughtering during holidays (14percent) which is similar with the result of Yenesew et al., who pointed that, most of the people keeping sheep for main purpose those were cash income, home consumption and security (Table 2).

Table 2 Fattening system of sheep identified in the study area

\begin{tabular}{|c|c|c|}
\hline Systems of sheep fattening & $\begin{array}{l}\text { Frequency } \\
(\mathrm{N}=8)\end{array}$ & $\begin{array}{l}\text { Percentage } \\
\text { (\%) }\end{array}$ \\
\hline Stall feeding & 48 & 60 \\
\hline Grazing with Stall feeding & 32 & 40 \\
\hline \multicolumn{3}{|l|}{ Housing system of fattening sheep } \\
\hline Common with total sheep & 27 & 33.75 \\
\hline Separate for fattening sheep & 53 & 97.9 \\
\hline
\end{tabular}

Livestock holding in the study area: The result of the existing study shown that the cattle the majority respondents of (71.25percent) Calf, (95percent) Heifer and (78.75percent) were ox cattle size (1-3) in the study area (Table 3). The result of the current study discovered that the flock of goat the majority respondents of (62.5percent) Buck, (77.5percent) Doe and (53.5percent) were kids goat size (1-3) in the study area (Table 3 ). The result of the current study revealed that the flock of sheep the majority respondents of (88.75percent) breeding ewes, (85percent) lambs and (75percent) were rams sheep size (13 ) in the study area (Table 3). The majority of the ewes in the flock indicate that famers maintain the breeding female stock with higher priority. The source of flock was mainly through purchase from the local market. Slight attempt has been made by government in introducing Dorper breed for crossing of the local.

Table 3 Purposes of keeping sheep in the studied area

\begin{tabular}{lll}
\hline Purposes of keeping sheep & $\begin{array}{l}\text { Frequency } \\
(\mathbf{N = 8 0 )}\end{array}$ & $\begin{array}{l}\text { Percentage } \\
(\%)\end{array}$ \\
\hline For income & 45 & 56 \\
Security & 24 & 30 \\
Home consumption & 11 & 14 \\
Total & 80 & $100 \%$
\end{tabular}

Feed sources and supplements of sheep in study area: The major feed resource of sheep in the study area were natural pasture, crop residue, improved forage and house leftover. Natural pasture and house leftover are the major feed resources during the rainy season whereas natural pasture, crop residue, improved forage and house leftover are the feed resources in the dry season. The result is similar with the report of Abebe et al., who pointed that, feed shortage is one of the limiting factors for increasing production and productivity of small ruminant in most of the agro-ecological zones in Ethiopia. The main feed source was communal grazing land, crop residues and crop stubble. Farmers supplement their sheep during fattening by treated maize, sweet potato, and tuber or vine and atella (Table 4\&5).

Table 4 Livestock holding in the study area

\begin{tabular}{llllllll}
\hline Livestock & Class & \multicolumn{2}{l}{ Livestock size } & & & & \\
\hline \multirow{4}{*}{ Cattle } & & 3-Jan & $\%$ & 7-Apr & $\%$ & $>8$ & $\%$ \\
& Calf & 57 & 71.25 & 10 & 12.5 & 13 & 16.25 \\
& Heifer & 76 & 95 & 4 & 5 & & \\
\multirow{5}{*}{ Goat } & Bull & 63 & 78.75 & 6 & 7.5 & & \\
& Buck & 50 & 62.5 & 9 & 11.25 & 2 & 2.5 \\
& Doe & 62 & 77.5 & 13 & 16.25 & 1 & 1.25 \\
\multirow{5}{*}{ Sheep flock } & Kids & 43 & 53.75 & 4 & 5 & & \\
& Ram & 60 & 75 & 12 & 15 & 8 & 10 \\
& Ewe & 71 & 88.75 & 9 & 11.25 & & \\
& Lambs & 68 & 85 & 8 & 10 & 4 & 5 \\
\hline
\end{tabular}

Table 5 Feed sources and supplements of sheep in study area

\begin{tabular}{llll}
\hline No & Major feed sources & Frequency $(\mathbf{N}=\mathbf{8 0})$ & Percentage (\%) \\
\hline 1 & Natural pasture & 38 & 47.5 \\
2 & House leftover & 19 & 23.75 \\
3 & Improved forage & 17 & 21.25 \\
4 & Crop residue & 6 & 7.5 \\
\hline
\end{tabular}


Table Continued...

\begin{tabular}{llll}
\hline No & Major feed sources & Frequency $(\mathbf{N}=\mathbf{8 0})$ & Percentage (\%) \\
\hline & Supplements during fattening & & \\
1 & Boiled maize & 42 & 52.5 \\
2 & Sweet potato tuber or vine & 15 & 18.75 \\
3 & Atella & 23 & 28.75 \\
& Total & 80 & $100 \%$ \\
\hline
\end{tabular}

Water sources and watering of fattening sheep in the study area: The result showed 52.5 percent, 12.5 percent and 35 percent were using river water, well water and both well and river water respectively.
In this study 77.5percent of the respondent responded they provide water at least once/day. However, 22.5percent of the farmers water the animals every two days and three days consecutively (Table 6).

Table 6 Water sources and watering of fattening sheep in the study area

\begin{tabular}{llll}
\hline No & Source of Water & Frequency $(\mathbf{N}=\mathbf{8 0})$ & Percentage (\%) \\
\hline I & River water & 42 & 52.5 \\
2 & Well Water & 10 & 12.5 \\
3 & Well \&River Water & 28 & 35 \\
& Watering frequency & & \\
I & At least Once/day & 62 & 77.5 \\
2 & Every two days & 18 & 22.5 \\
& Total & 80 & $100 \%$ \\
\hline
\end{tabular}

Condition for selecting fattening sheep in the study area: The result of current study indicated that farmers in the study area select sheep on age through dentition, body condition, coat color and sex to some extent (Table 6). The most desired colors of sheep in market were Dalecha and white where as black sheep were badly preferred. Sheep with poor body condition were not selected for fattening. Male sheep were given higher choice than females during selection. Castration of animals was also another creation for fattening in the study area. Accordingly, (77.5 percent) of the respondents either castrate or purchase castrated sheep for fattening while the remaining (22.5 percent) of the respondents used both castrate and intact. Matured sheep which are within the age range of 1-2 years had got higher choice in selection over the young ones ( 68.75 percent). The result is supported by the findings of Getachew and Jane.

\section{Sheep marketing system identified in the study area}

\section{Sheep marketing in study area}

A typical sheep and goat marketing structure/chain based on a typical livestock market structure identified by Ayele et al., ${ }^{8}$ and sheep and goat marketing structure. ${ }^{9}$ The main actors of the 1 st level are local farmers and rural traders/rural assemblers who transact at farm level. Those small traders from different corners bring their animals to the local market (2nd level). Traders/wholesalers purchase a few large animals or a fairly large number of small animals for selling to the secondary markets. In the secondary market (3rd level), both smaller and larger traders operate and traders (wholesalers or retailers) and butchers from terminal markets come to buy animals. In the terminal markets (4th level), big traders and butchers (wholesalers or retailers) transact larger number of mainly slaughter type animals.
Consumers get meat through direct purchase of live animals or from butchers. In Duna woreda/Ansho, farmers market sheep at farm gates or the nearest local/primary markets. Farmers and rural assemblers from different local markets supply animals of varying sex, age and weight to Ansho and Cafemera secondary markets. There were two possible exit market routes through which animals from Ansho area reach to the final consumers. The first route was through agents of export abattoirs who collect young male sheep from the local markets while the second and most important route was through medium and large traders who collect animals from Duna woreda/Ansho areas and supply through large traders to terminal domestic markets in Hosanna and Addis Ababa. Animals that exist through the later routes were often exceptionally fattened male animals usually supplied during holidays. In the second and third levels (primary and secondary markets), animals were bought for breeding and fattening purposes.

\section{Fattening season of sheep study area}

With regard of season fattening and marketing, (58.75percent) of respondents practice fattening at the time of holiday; however, (41.25percent) of them practice on both holiday and non-holiday. Season of cattle fattening agrees with the report of Getachew and Jane who reported that small scale sheep fattening in Ethiopia followed a seasonal operation with a peak during Easter, Christmas, Ethiopian New Year and Muslim festivities. Marketing of sheep was completed through negotiation. In the process of sheep marketing, farmer, middle men and traders were involved. According to the present study, the fatteners sold their fattened sheep by negotiation with customer in the study area. The price of fattening sheep depends on body condition, castration, age, color and ranging from 2000-4500 ETB (Table 7). 
Table 7 Criterion for selecting fattening sheep

\begin{tabular}{|c|c|c|c|}
\hline No & Criterion for selecting fattening sheep & Frequency $(\mathrm{N}=\mathbf{8 0})$ & Percentage (\%) \\
\hline \multirow[t]{3}{*}{ I } & Sex & & \\
\hline & Male sheep & 54 & 67.5 \\
\hline & Female sheep & 26 & 32.5 \\
\hline \multirow[t]{3}{*}{2} & Age & & \\
\hline & Younger & 25 & 31.25 \\
\hline & Matured & 55 & 68.75 \\
\hline \multirow[t]{4}{*}{3} & Condition & & \\
\hline & Poor & 10 & 12.5 \\
\hline & Medium & 60 & 75 \\
\hline & High & 10 & 12.5 \\
\hline \multirow[t]{4}{*}{4} & Coat color & & \\
\hline & White & 15 & 18.75 \\
\hline & Dalecha & 50 & 62.5 \\
\hline & Any type & 15 & 18.75 \\
\hline \multirow[t]{4}{*}{5} & Castration & & \\
\hline & Both & 18 & 22.5 \\
\hline & Castrated & 62 & 77.5 \\
\hline & Total & 80 & $100 \%$ \\
\hline
\end{tabular}

\section{Length and frequency of sheep fattening in study area}

The result of current study indicated that the average duration of fattening as responded by the majority of farmers was three months for matured sheep where as it might extend to 4 months for the young

Table 8 Fattening season and marketing of sheep study area

\begin{tabular}{llll}
\hline No & Variables & Frequency $(\mathbf{N}=\mathbf{8 0})$ & Percentage (\%) \\
\hline I & $\begin{array}{l}\text { Fattening season } \\
\text { During holidays }\end{array}$ & 47 & 58.75 \\
& $\begin{array}{l}\text { Holidays and non- } \\
\text { holidays }\end{array}$ & 33 & 41.25 \\
Marketing system & & \\
Negotiation with & 22 & 27.5 \\
consumer & 28 & 35 \\
To middle men & 20 & 37.5 \\
To traders & 30 & $100 \%$ \\
Total & &
\end{tabular}

sheep. This is in the study area finish sheep in agreement with the finding of Getachew and Jane that reported most farmers in the study area finish sheep in three months. Based on the peak periods of marketing, farmers practice 2-3 times a year to catch public festivals as opportunities (Table $8 \& 9$ ).

Table 9 Length and frequency of sheep fattening in study area

\begin{tabular}{llll}
\hline No & Variables & Frequency $(\mathbf{N}=\mathbf{8 0})$ & Percentage (\%) \\
\hline 1 & Duration of fattening (months) & \\
2 & 14 & 17.5 \\
3 & 50 & 62.5 \\
& 4 & 16 & 20 \\
2 & Frequency of fattening (round) & \\
& Once & 15 & 18.75 \\
& $\begin{array}{l}\text { Twice } \\
\text { More than }\end{array}$ & 50 & 62.5 \\
twice & 15 & 18.75 \\
Total & 80 & $100 \%$ \\
\hline
\end{tabular}




\section{Conclusion}

Sheep production was common practice in Duna Woreda due to suitable agro ecology that makes the Woreda potential for sheep production and marketing. Fattening sheep in feedlot system $(60$ percent) and grazing and stall feeding (40 percent) were the major fattening systems identified in the area. The high proportion of producers provided crop residues and grazing of natural grasses. Farmers market sheep at farm gates or the nearest local/primary markets. In the process of sheep marketing, farmer, middle men and traders were involved. The fatteners sold their fattened sheep through negotiation with customer in the study area. Farmers and rural assemblers from different local markets supplied animals of varying sex, age and weight to Ansho and Cafemera secondary markets. The second and most important route was through medium and large traders who collect animals from Duna woreda/Ansho areas and supply through large traders to terminal domestic markets in Hosanna and Addis Ababa. Based on the result of the current study, utilization of improved forage and house leftover was appreciated and intensive training on sheep fattening, marketing and management in addition to further work is needed to develop a cost effective feeding strategy by combing improved and locally available feed resources for better productivity and profitability. ${ }^{10-21}$

\section{Acknowledgments}

None.

\section{Conflicts of interest}

We declare that there are no conflicts of interest.

\section{References}

1. Azage T. Institutional arrangement and challenges in market printed livestock agriculture in Ethiopia animal society's animal production held in Addis Ababa. EAP. 2006;9;10-12.

2. Gizaw Solomon, Van Arendonk JAM, Komen H, et al.. Population structure, gentic variation and morphological diversity in indigenous sheep of Ethiopia. Animal Genetics. 2007;38:621-628.

3. Solomon G. Sheep production and marketing system sheep in Ethiopia. Ethiopia: International livestock institute Addis Ababa; 2010.

4. Banners A. Selection and breeding strategy for increase productivity of sheep in Ethiopia. 2000.

5. ESGPIP. Ethiopia sheep and goat productivity improvement program. 2008.

6. Addis Getu. Review on Challenges and Opportunities Sheep Production: Ethiopia. Ethiopia: Department of Animal Production and Extension, Faculty of Veterinary Medicine, University of Gondar; 2015.

7. Duna Woreda Agriculture and Rural Development Office. 2013.
8. Ayele S, Assegid W, Jabbar MA, et al. Livestock marketing in Ethiopia: $A$ review of structure, performance and development initiatives. Kenya: Socio-economics andPolicy Research Working Paper 52. ILRI (International Livestock Research Institute), Nairobi; 2013.

9. Tsedeke Kotcho. Production and marketing of sheep and goats in Alaba, SNNPR. Ethiopia: An Msc Thesis presented to school of Graduate Studies of Hawassa University. Hawassa Ethiopia; 2007.

10. Belachew H, Jemberu E. Challenges and opportunities of livestock marketing in Ethiopia. Ethiopia: proceedings of $10^{\text {th }}$ annual conference of the Ethiopian society of animal production (ESAP) ESAP (Ethiopia society of animal production). Addis Ababa; 2003; P. 1-13.

11. CSA (Central Statistical Agency of Ethiopia). Demographic and Health survey. 2007.

12. CSA (Central statistics Authority). The 2001/02 Ethiopia agriculture sample enumeration (EASE), Executive summary. Addis Ababa, Ethiopia; 2004 .

13. Devendra C, Burns M. Goat Production in the tropics common wealth agricultural bureau, London, UK; 1983. P. 183.

14. EARO (Ethiopian Agricultural Research organization). National small ruminants research strategy document EARO, Addis Ababa, Ethiopia; 2000

15. EARO (Ethiopian Agricultural Research organization). Feeds and nutrition research strategy EARO (Ethiopian Agricultural Research organization), Addis Ababa; 2001b. P. 40.

16. Kebede Andargachew, Ray B. Intra-annual sheep price patterns and factors underlying price variations in the central highlands of Ethiopia. In: Rey B, Lebbie SHB, Reynolds L, editors. Kenya: Small ruminant research and development in Africa. Proceedings of the first biennial conference of the African small ruminant research network, ILRAD, Nairobi; 1990. P. 1-10.

17. Samuel M. Characterization of livestock production system: The case of East Showa. Ethiopia: Msc. Thesis Alemaya University. Ethiopia. Small Dairy Development Project (SDDP), Addis Ababa, Ethiopia; 2008.

18. Solomon G. Sheep resources of Ethiopia: Genetic diversity and breeding strategy. Ethiopia: A PhD Thesis Presented to Wageningen University; 2008; P. 145.

19. Tesfaye Tsegaye. Characterization of goat production systems and onfarm evaluation of the growth performance of grazing goats supplemented with different protein sources in Metema woreda, Amhara region, Ethiopia. Ethiopia: MSc thesis.Haramaya University; 2009.

20. Tibbo M. Productivity and health of indigenous sheep breeds and crossbreds in the central Ethiopia highlands. Sweden: Swedish University of Agricultural Science (SLU), Uppsala; 2006.

21. Zelalem Tamrat. Adoption of small ruminant fattening package in agropastoral areas, Meisowereda, Eastern Oromia. Ethiopia: MSc thesis. Haramaya University, Haramaya; 2007. 